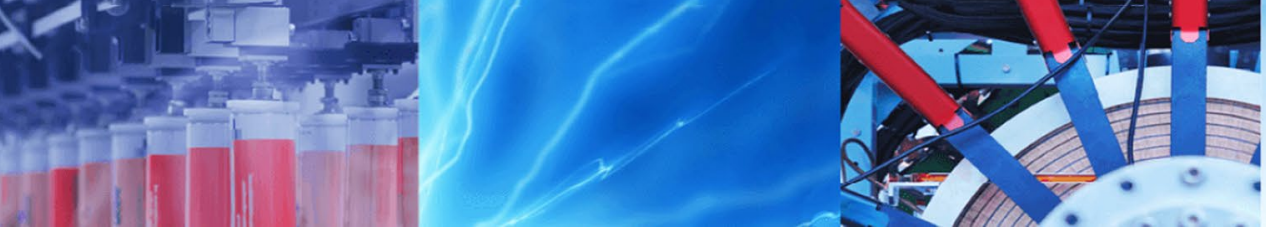

Research Article

\title{
Increased average annual prevalence of upper respiratory tract infection (UTRI) in the central Indian population residing near the coal-fired thermal power plants
}

\author{
Puspita Barik $^{1,2} \cdot$ Pravin Naoghare $^{3} \cdot$ Saravanadevi Sivanesan $^{2} \cdot$ Krishnamurthi Kannan $^{2} \cdot$ Anirban Middey $^{4}$
}

Received: 19 September 2020 / Accepted: 14 January 2021 / Published online: 25 January 2021

(c) The Author(s) 2021 OPEN

\begin{abstract}
People are vulnerable to health risks due to particulate matter generated through the coal combustion processes. The air pollution due to the thermal power plant is a primary concern among all sources of pollution. The air pollution due to the coal-fired thermal power plant is a primary concern among all the different sources of pollution. The air quality (suspended particulate matter; SPM) modeling in the study area of central India was carried out using CALAUFF model. In addition, real-time air monitoring of particulate matter $\mathrm{PM}_{1}, \mathrm{PM}_{2.5}$ and $\mathrm{PM}_{10}$ was carried out in the study area. Real-time air quality monitoring data showed higher concentration of particulate matter $\left(\mathrm{PM}_{1}\right.$ and $\left.\mathrm{PM}_{2.5}\right)$ at different locations in the study area, exceeding the regulatory limits set by NAAQS (National Ambient Air Quality Standards) and WHO (World Health Organization). Considering the most probable health impacts due to coal-fired thermal power plant, diseases such as chronic upper respiratory tract infections (URTI), and asthma were focused in this study. Hospital admission data were collected for respiratory disorders from six different public health centers (PHCs) located in the study area for the years 2012 and 2013. Average annual prevalence (AAP) of asthma at Dhapewada, Patansaongi, Chicholi, Satak, Droli and Kanhan PHCs was observed to be $0.581,0.218,0.201,0.155,0.377$ and $0.198 \%$, respectively, whereas AAP of UTRI at Dhapewada, Patansaongi, Chicholi, Satak, Droli and Kanhan PHCs was 24.961, 40.693, 0.769, 12.775, 28.605 and 14.898\%, respectively. Thus, we conclude that the study population residing nearby the coal-fired thermal power plants may have an increased risk to upper respiratory tract infections (URTI) than asthma.
\end{abstract}

Keywords Air pollution · CALPUFF dispersion model · Particulate matter · Hospitalization · Prevalence of respiratory disorder

$\begin{array}{ll}\text { Abbreviations } \\ \text { CFTPP } & \text { Coal-Fired Thermal Power Plant } \\ \text { URTI } & \text { Upper Respiratory Tract Infection } \\ \text { ARI } & \text { Acute Respiratory Infection } \\ \text { AAP } & \text { Average Annual Prevalence } \\ \text { OPD } & \text { Outpatient Department } \\ \text { PM } & \text { Particulate Matter } \\ \mathrm{SO}_{2} & \text { Sulfur dioxide }\end{array}$

\section{Abbreviations}

URTI Upper Respiratory Tract Infection

Acute Respiratory Infection

AAP Average Annual Prevalence

PM Particulate Matter ESP

$\begin{array}{ll}\text { NOx } & \text { Nitrogen Oxide } \\ \text { GPS } & \text { Global Positioning System } \\ \text { PHC } & \text { Primary Health Center } \\ \text { GLC } & \text { Ground-Level Concentration } \\ \text { DHO } & \text { District Health Officer } \\ \text { SPM } & \text { Solid Particulate Matter } \\ \text { ESP } & \text { Electrostatic Precipitators (ESP }\end{array}$

Puspita Barik, puspitabarik54@gmail.com; $₫$ Krishnamurthi Kannan, k_krishnamurthi@neeri.res.in | ${ }^{1}$ Academy of Scientific and Innovative Research (AcSIR), Ghaziabad 201002, India. ${ }^{2}$ Health and Toxicity Cell (HTC), CSIR-National Environmental Engineering Research Institute, Nagpur, Maharashtra, India. ${ }^{3}$ Environmental Impact and Sustainability Division (EISD), CSIR-National Environmental Engineering Research Institute, Nagpur, Maharashtra, India. ${ }^{4}$ Air Pollution Control Division (APC), CSIR-National Environmental Engineering Research Institute, Nagpur, Maharashtra, India. 


\section{Introduction}

Coal-fired thermal power plants (CFTPP) are significant contributors to the generation of electricity in many developing countries. It almost generates $40 \%$ of electricity worldwide [1]. The large number of coal-fired thermal power plants in India continuously releases fly ash from their stacks. Depending upon the meteorological conditions, it gets dispersed in the surrounding area. The fine particulate matter (size $\leq 10 \mu \mathrm{m}$ ) remains suspended in the air up to a certain distance and eventually gets grounded. The scientific literature entails seasonal variation or spatial variability of PM in the locality of CFTPP in India [2-7].

Fly ash contains traces of elements like arsenic, cadmium, lead, mercury, etc., which can contaminate environmental sources (air, water, and soil) and cause adverse health effects [8-10]. The CFTPP emit particulate matter (PM), sulfur dioxide $\left(\mathrm{SO}_{2}\right)$ and nitrogen oxides (NOx) into the atmosphere $[4,11,12]$. Due to this, CFTPP are considered as localized sources of elevated air pollution. Studies are available on the toxic evaluation of aerosols in the vicinity of Indian CFTPP [13]. Contaminants emitted from CFTPP are associated with the adverse health impacts to humans in the form of respiratory and other diseases [14-16]. Particulate matter (PM) is the known triggers for upper respiratory tract infections and asthma attacks $[17,18]$. Various authors $[19,20]$ have investigated the adverse health impact of airborne particulate matter $[21,22]$. But the studies on the association of localized PM concentrations on the respiratory illness (UTRI and asthma), especially in central Indian context, are not well documented. Thus, the primary objective of this study was to understand the risk to respiratory diseases [upper respiratory tract infection (UTRI) and asthma] in the central India population residing near the vicinity of coal-fired thermal power plants.

\section{Materials and methods}

\subsection{Study area}

Thermal power plants located about $20 \mathrm{~km}$ in the north of Nagpur city were identified as one of the target sources present in central India. Koradi thermal power plant was commissioned in 1974 with a first unit of $115 \mathrm{MW}$. Thereafter, augmentations were done in stages and today after four stages, plant has ten units. The plant has a total power generation capacity of $1700 \mathrm{MW}$ and is wholly coal based. Another power plant at Khaperkheda is located about $3.5 \mathrm{~km}$ to the north east of Koradi thermal power plant. This plant was commissioned during 1989 and is operating with five units with a capacity of $1340 \mathrm{MW}$. Four units are of $210 \mathrm{MW}$ each and the fifth unit is of $500 \mathrm{MW}$. This is also a coal-based plant. More details about these plants are given in Table 1.

Six primary health centers $(\mathrm{PHC})$ were selected in the study area, namely Chicholi $\left(21.4876^{\circ} \mathrm{N}, 79.7091^{\circ} \mathrm{E}\right)$, Dorli $\left(21.2632^{\circ} \mathrm{N}, 78.7845^{\circ} \mathrm{E}\right)$, Dhapewada $\left(21.2316^{\circ} \mathrm{N}, 78.9174^{\circ}\right.$ E), Patansawangi $\left(79.0207^{\circ} \mathrm{E} 79.0207^{\circ} \mathrm{E}\right)$, Gomthi $\left(21.1461^{\circ}\right.$ $\left.\mathrm{N}, 79.0615^{\circ} \mathrm{E}\right)$ and Kanhan $\left(21.2297^{\circ} \mathrm{N}, 79.2381^{\circ} \mathrm{E}\right)$ (Fig. 1). The dispersion modeling outputs were referred to decide the study region surrounding the two plants. Based on the average yearly concentration profiles of PM, the area under $20 \mathrm{~km}$ radial distance from the plants was considered as the study region. Since this region mostly spans the rural sector, villages in this region and the population therein were targeted for the possible health hazards due to CFTPP based pollution. The PHC governed by the Ministry of Health, State Government of Maharashtra were

Table 1 Various equipment's used according to the environmental protection

\begin{tabular}{|c|c|c|c|c|c|c|}
\hline Sr. no & Unit & Stack attached & Height (m) & Air pollution control equipment & Designed efficiency & Fuel type \\
\hline \multicolumn{7}{|c|}{ Khaperkheda thermal power plant: Location $\left(21.2639^{\circ} \mathrm{N}, 79.1095^{\circ} \mathrm{E}\right)$} \\
\hline 1 & Boiler unit I, II, III, IV and V & $\begin{array}{l}\text { Common stock } \\
\text { for Boiler Unit-I } \\
\text { to Unit II }\end{array}$ & 220 & $\begin{array}{l}\text { Electrostatic precipitators (ESP) } \\
\text { with manual ammonia dosing }\end{array}$ & $99.917 \%$ & Coal \\
\hline 2 & & $\begin{array}{l}\text { Common stock } \\
\text { for boilers } \\
\text { for Unit-III to } \\
\text { Unit-IV }\end{array}$ & 220 & ESP & $99.938 \%$ & \\
\hline 3 & & Boiler for Unit-V & 275 & ESP & $99.91 \%$ & \\
\hline \multicolumn{7}{|c|}{ Koradi thermal power plant: Location $\left(21.2378^{\circ} \mathrm{N}, 79.1125^{\circ} \mathrm{E}\right)$} \\
\hline 4 & Boiler Unit No: V, VI, VII & Boiler Unit-V & 90 & Bag filter + ESP & $99.917 \%$ & Coal \\
\hline 5 & & Boiler Unit- VI & 90 & Bag filter + ESP & $99.938 \%$ & \\
\hline 6 & & Boiler Unit- VII & 90 & ESP & $99.9 \%$ & \\
\hline
\end{tabular}


Fig. 1 Map showing the study area with six public health centers

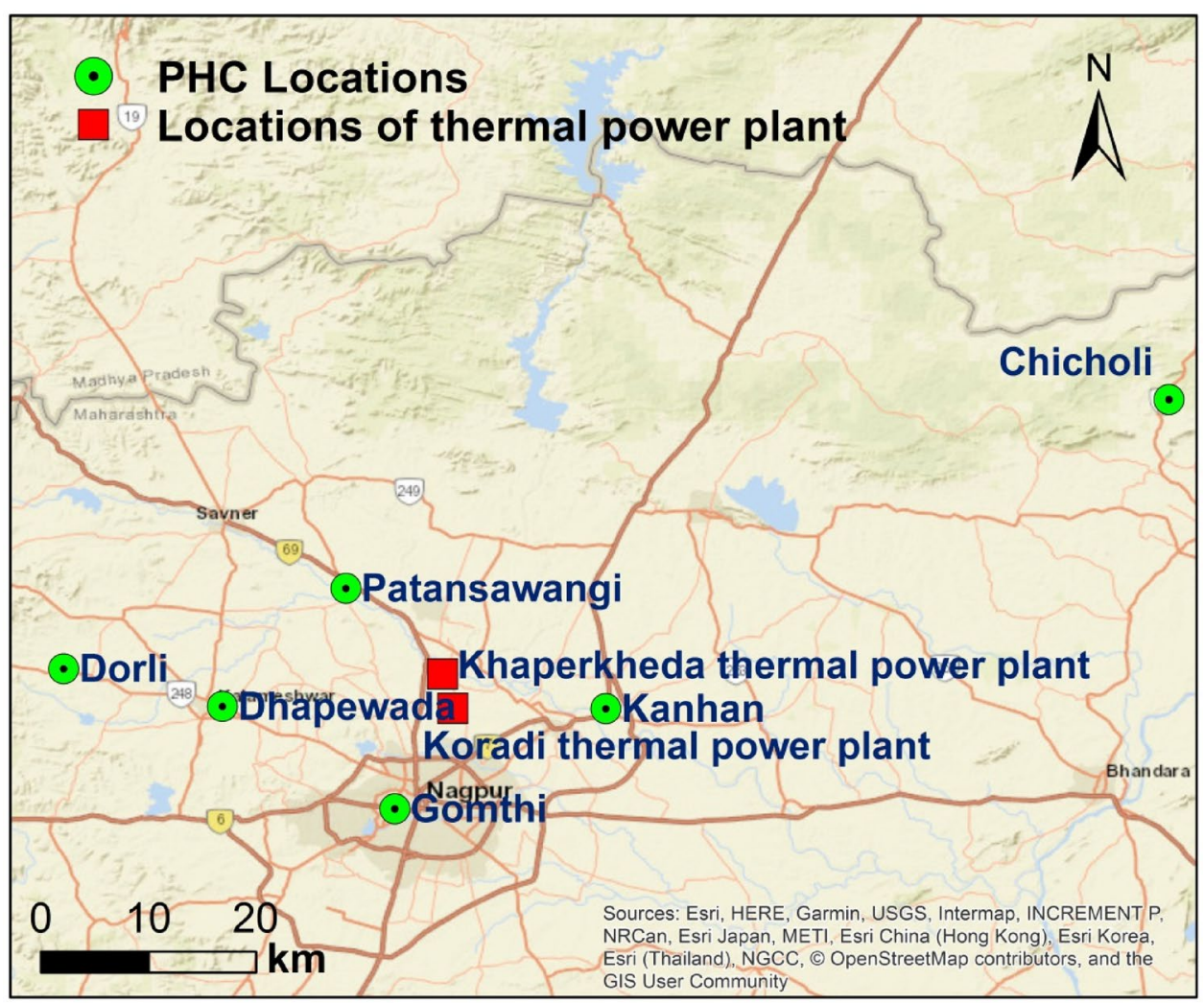

approached, and the list of villages served by each PHC was obtained.

\subsection{Ambient air quality}

\subsubsection{Dispersion modeling using CALPUFF model}

Epidemiological studies require monitoring on two issues, i.e., the health status of the subjects in the study area and the ambient air quality to which they are continuously exposed. The air quality can be determined by two major tools, one is on-site air quality monitoring, and the other is the use of mathematical models to predict air quality. Field monitoring is a resource-intensive exercise requiring logistics like electric power supply, accessibility to the monitoring station, the safety of equipment, security of monitoring staff, etc. It also requires regular calibration of the equipment, transfer of collected representative air samples, its storage, conditioning in the laboratory, sample analysis followed by data analysis. Such field monitoring exercise can be substituted by source dispersion modeling exercise if all the sources can be identified and its emission quantified. The quantification of source emission rate requires knowledge of the type of emission, i.e., point, area or line source, followed by emission characteristics like the height of emission above ground, exit velocity of emission, the temperature of emission and mass of emission per unit time.

For a well-defined elevated point source, the dispersion model works efficiently as the source emission characteristics can be determined accurately. However, ground-level sources, like vehicular emission, area source emission, etc., the emission rate estimates and source geometry are not very precise. Therefore, uncertainty for area and line sources is relatively more complex. However, dispersion gives an overall satisfactory picture of the dispersion of pollutants that helps in decision making.

The CALPUFF is a non-stable-state-run, multilayer Lagrangian puff model for the estimation of deposition/ concentration patterns for multiple air pollutants by considering the effects of space-time by varying meteorological conditions. Puff dispersion is Gaussian, and concentrations are based on the contribution of each puff as it passes over or near a receptor point for industrial pollutants [23-25]. In order to determine the exposure concentration of PM contributed by emission from the thermal power plant, the required parameters, as described in the methods section, were put in to the CALPUFF model. The dispersion profiles were obtained season-wise for summer (April-June), post-monsoon (September-October) and winter (January-February) seasons, as well as the average annual maximum profile of PM, were also obtained for 24-h intervals. The dispersion of the air pollutant from 
the point source (TPP) was mainly dependent on the wind distribution associate with the meteorological condition of the study area. These types of findings were also observed in Yuma/San Luis USA/Mexico [26]. In this study, the latitude- and longitude-wise concentration data, as an output of dispersion modeling, was inputted to EpiHRA software to display SPM contours around the source. The contours were obtained for each season giving the average daily concentration for the season. The average annual profile provides the average maximum concentration pooled over the year. Input data are given in Table 2.

One-year meteorology is considered for the study and ground-level concentration (GLC) of PM pollutants for four scenarios considered. The scenario is different in various season, viz., winter, summer, post-monsoon and annual average GLC of PM. The period (2012-13) considered for simulation was for winter, summer, post-monsoon and average. $\mathrm{PM}_{10}$ concentration data due to emission from TPP was obtained through a dispersion model using CALPUFF software. The data on plant production capacity, the meteorological conditions are inputted to software to obtain the isopleths around the source in the pre-defined region. For the present study, the isopleths were obtained season-wise, giving the average daily concentrations as well as average annual maximum daily concentrations. The concentration data were obtained as per latitude and longitude in the square grid of $20 \times 20 \mathrm{~km}$. The source-specific concentration data were correlated with the disease status.

\subsubsection{Real-time air quality monitoring}

In addition to the dispersion modeling, real-time air monitoring was carried out during March 2020. The air sampling was carried out at seven locations around the Koradi and Khaperkheda thermal power plants (Fig. 2). The sampling locations, namely Mankapur, Koradi, Suradevi, Gagoli, masala, Arti town colony and Satak, were chosen. The air sampler, Portable Laser Aerosol spectrometer and Dust
Monitor Model 1.108/1.109 with polytetrafluoroethylene (PTFE) filter were used for the air sampling at the flow rate of $16.7 \mathrm{~L} / \mathrm{min}$ for 8 -h duration and a total of three filters were collected at each sampling location for $24 \mathrm{~h}$. The data were recorded for every 1-min interval. The average concentrations of $\mathrm{PM}_{10}, \mathrm{PM}_{2.5}$ and $\mathrm{PM}_{1}$ at each location were identified.

\subsection{Secondary health data}

\subsubsection{Identification of medical centers and secondary health data collection}

The approval from the institutional ethics committee was taken before the execution of the study (Reference No: Eth.com. /01/IEC/EHD/2/2014). The obtained admission records for respiratory diseases (January 2012-December 2013) from six primary health centers represent the data. These records contain season-wise admission in PHC. Permission was sought from the District Health Officer (DHO), Nagpur, to visit the identified primary health care centers for collection of secondary data on health. Accordingly, medical officers from these centers were contacted to understand the health status of villagers in their respective villages. They were explained the purpose of the study and the need for health data. It was observed that as per guidelines of state government, each PHC maintains records of patients in hard copy format, and the monthly summarized data are sent to headquarters electronically. The summarized data feature: (i) the number of patients attending Outpatient Department (OPD) (ii) age and gender distribution, (iii) disease-wise distribution of patients, (iv) other details like medicine stocks, staff details, medical equipment details, etc.

The data of interest, i.e., the number of patients attending OPD as per age and gender, type of disease, was made available by each identified PHC. The data for the years 2012 and 2013 were collated from the six centers. One limitation was that not all the centers had gathered data
Table 2 Emission sources considered for dispersion modeling

\begin{tabular}{lllllc}
\hline Stack ID & $\begin{array}{l}\text { Stack height } \\
(\mathrm{m})\end{array}$ & $\begin{array}{l}\text { Top diameter } \\
(\mathrm{m})\end{array}$ & $\begin{array}{l}\text { Exit velocity } \\
(\mathrm{m} / \mathrm{s})\end{array}$ & $\begin{array}{l}\text { Temperature } \\
(\mathrm{K})\end{array}$ & $\begin{array}{l}\text { Emission } \\
\text { rate }(\mathrm{g} / \mathrm{s})\end{array}$ \\
\hline Khaperkheda TPP Twin1A & 220 & 5 & 20 & 418 & 123 \\
Khaperkheda TPP Twin1B & 220 & 5 & 20 & 418 & 123 \\
Khaperkheda TPP Twin2A & 220 & 5 & 20 & 418 & 123 \\
Khaperkheda TPP Twin2B & 220 & 5 & 20 & 418 & 123 \\
Khaperkheda 500 MW & 275 & 5 & 20 & 418 & 82 \\
Koradi3_200MW & 220 & 5 & 20 & 418 & 123 \\
Koradi4_210MW & 220 & 5 & 20 & 418 & 123 \\
Koradi5_210MW & 220 & 5 & 20 & 418 & 123 \\
Koradi6_660MW & 275 & 5 & 20 & 418 & 82 \\
\hline
\end{tabular}


Fig. 2 Map is showing study areas with air sampling locations

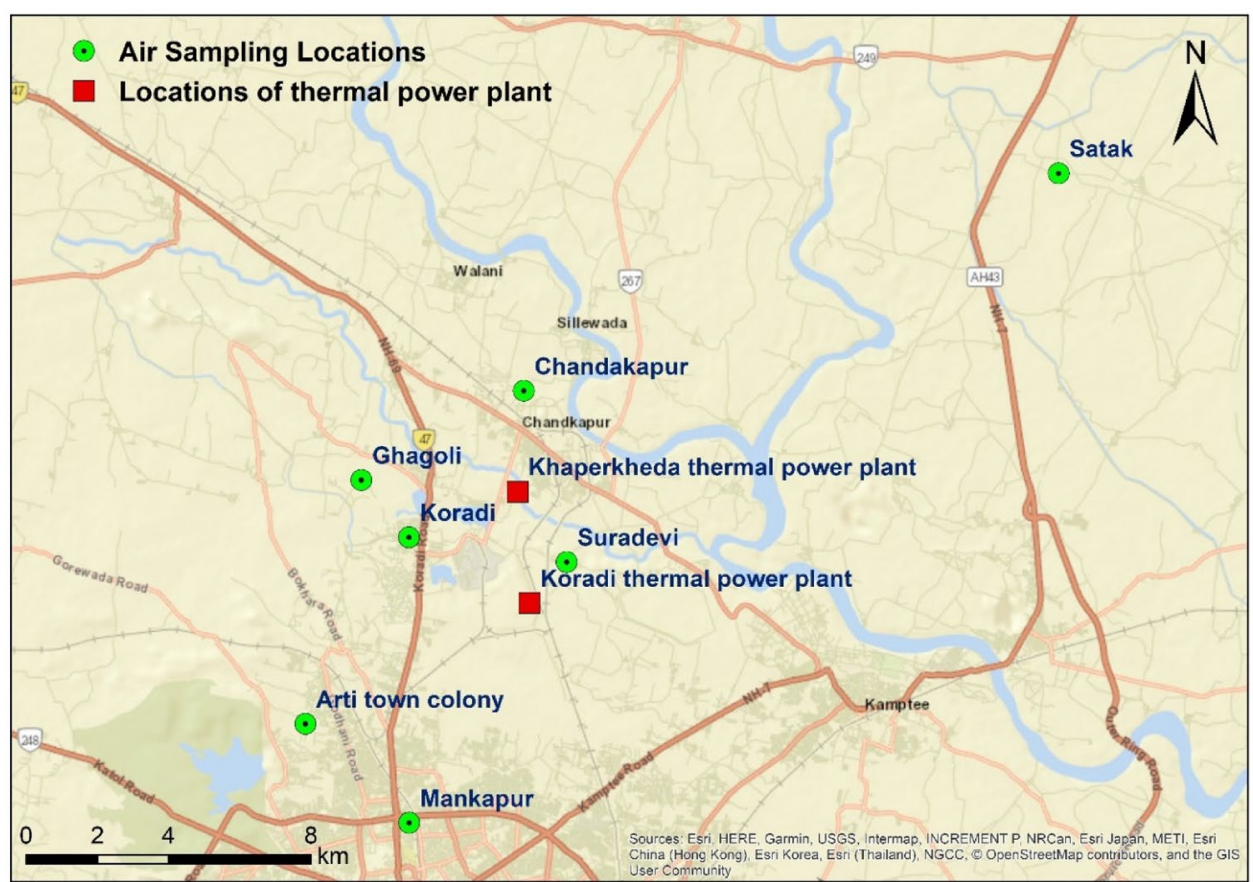

on the age of patients correctly; hence, the only gender of patients was included in the study. The data were eventually used to understand the prevalence of each disease in the study region.

\subsubsection{Analysis of secondary data}

The data obtained from selected health centers on the number of cases reporting with asthma and upper respiratory tract infections during the years 2012 and 2013 were expressed in terms of parameters like the periodic prevalence of disease and average annual prevalence of the disease. The expressions used for estimating these parameters are as below:

2.3.2.1 Periodic prevalence of the disease It is defined as the proportion of the population that has the disease condition during the given period (season) as well as at the start of the period.

2.3.2.2 Average annual prevalence The average annual prevalence of the disease is given by the expression (Eq. 1) [27]:

$P_{i j}=\frac{\left(100 d_{i j}\right)}{\left(n \times r_{j}\right)}$

where $i$ refers to disease type, $j$ is the location (PHC in this case), $d_{\mathrm{ij}}$ denotes total number of patients suffering from disease, $r_{\mathrm{j}}$ indicates total population at $j$ th place and $n$ denotes number of years of data.

\section{Results and discussion}

\subsection{Ambient air monitoring}

The average daily concentration of the airborne PM concentration is shown in Figure 3a. The results show PM contour of annual average maximum daily concentrations in the plant (approximately $2-3 \mathrm{~km}$ radius) were above $45 \mu \mathrm{g} / \mathrm{m}^{3}$, which is above WHO standards [28] while the majority of the region had a concentration below $45 \mu \mathrm{g} /$ $\mathrm{m}^{3}$. The higher concentration profile is spread over southwest to northeast direction from concerning the plant. Figure $3 \mathrm{~b}$ shows the contour plot of the summer season, and from the wind rose diagram the maximum wind flow shows that northwest direction maximum speed (3.6-5.7 m/s). The minimum average daily concentration was $0.032 \mu \mathrm{g} / \mathrm{m}^{3}$, while the maximum average daily concentration was $11.99 \mu \mathrm{g} / \mathrm{m}^{3}$ and the 90th percentile was $3.762 \mu \mathrm{g} / \mathrm{m}^{3}$. The display of contours showed a higher concentration trend toward the east and southeast of the source. Figure $3 \mathrm{c}$ reports the PM contour plot for the postmonsoon season. The minimum average daily concentration was $0.418 \mu \mathrm{g} / \mathrm{m}^{3}$, while the maximum was $11.510 \mu \mathrm{g} /$ $\mathrm{m}^{3}$ and the 90th percentile was $4.463 \mu \mathrm{g} / \mathrm{m}^{3}$. The higher concentrations were observed in the southwest direction of the plant in this season. Figure $3 \mathrm{~d}$ reports the of PM contour plot for the winter season. The minimum average daily concentration was $0.182 \mu \mathrm{g} / \mathrm{m}^{3}$, while the maximum was $10.553 \mu \mathrm{g} / \mathrm{m}^{3}$ and 90th percentile was $5.109 \mu \mathrm{g} / \mathrm{m}^{3}$. The higher concentrations were observed in the southwest and south direction of the plant in this season. The 
Fig. 3 a SPM contour of annual average maximum daily concentration, $\mathbf{b}$ visualization of SPM contour plot for summer season, $\mathbf{c}$ visualization of SPM contour plot for post-monsoon season and $\mathbf{d}$ visualization of SPM contour plot for winter season a

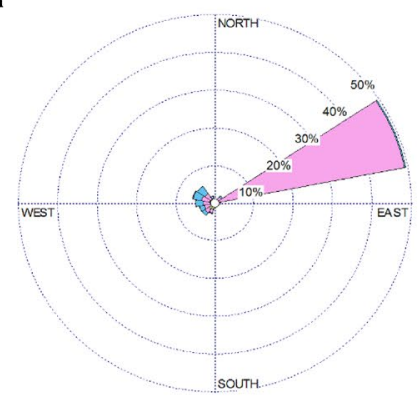

WIND SPED $(m / s)$ $=11,10$
$880-11.10$ $5.70 \cdot 8.80$
$3.60-5.70$ $210 \cdot 3.60$
$0.50 \cdot 2.10$ Cams: $10.02 \%$

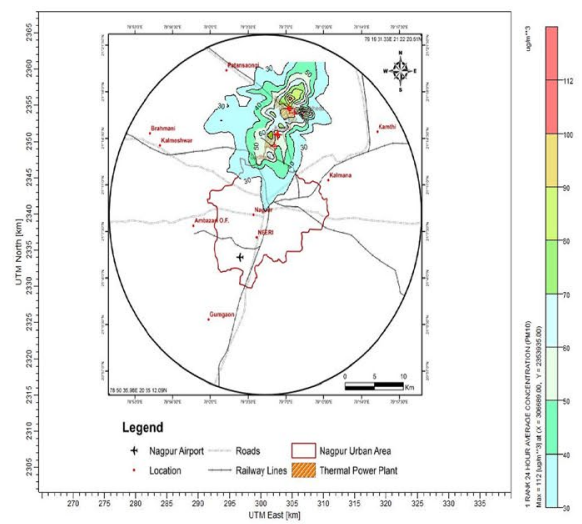

b
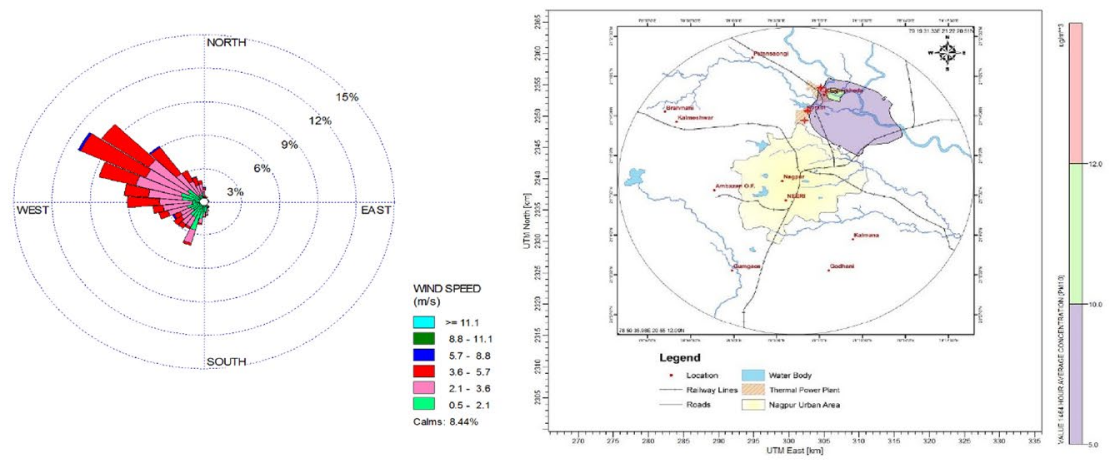

C
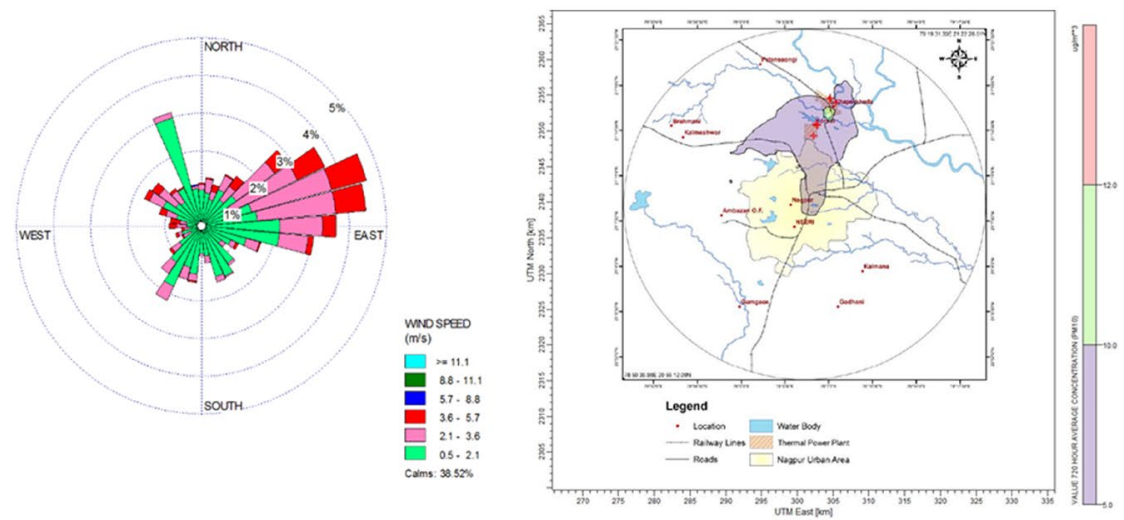

d

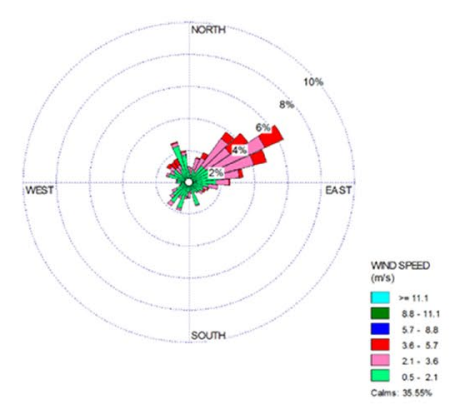

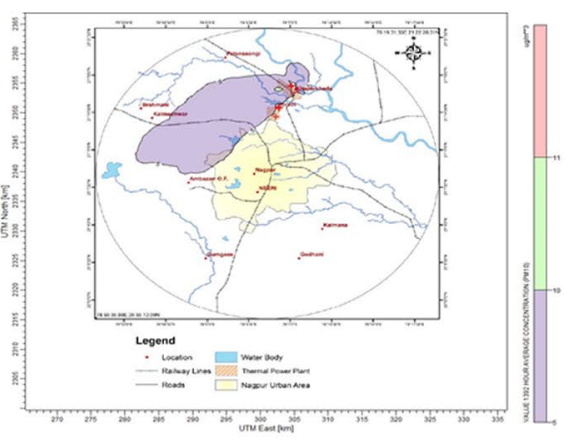


average annual prevalence (AAP) of UTRI was observed higher in the majority of locations. The concentration of PM is significantly highest in summer followed by decreasing post-monsoon and winter. The concentration observed by CALAUFF modeling is (summer $>$ post-monsoon $>$ winter) in order.

WHO [28] has set an annual permissible limit for air particulate matters of $20 \mu \mathrm{g} / \mathrm{m}^{3}$ and $10 \mu \mathrm{g} / \mathrm{m}^{3}$ for $\mathrm{PM}_{10}$ and $\mathrm{PM}_{2.5}$, respectively. In this study, the data obtained by dispersion modeling (Fig. 3a, b, c and d) revealed that the average concentration of $\mathrm{PM}_{10}$ in all sites within $(2-3 \mathrm{~km})$ the radius exceeded the permissible limit. The particulate matter concentration was higher in the area present near the Koradi and Khaperkheda thermal power plant.

The average $\mathrm{PM}_{10}, \mathrm{PM}_{2.5}$ and $\mathrm{PM}_{1}$ concentration levels at different locations in the study area are shown in Fig. 4 and Table 3. It can be clearly seen that PM concentrations at most of the locations were exceeding the NAAQS and WHO standards. Highest concentrations of $\mathrm{PM}_{10}, \mathrm{PM}_{2.5}$ and $\mathrm{PM}_{1}$ were observed at Mankapur location in the morning hours followed by the Arti town colony location.
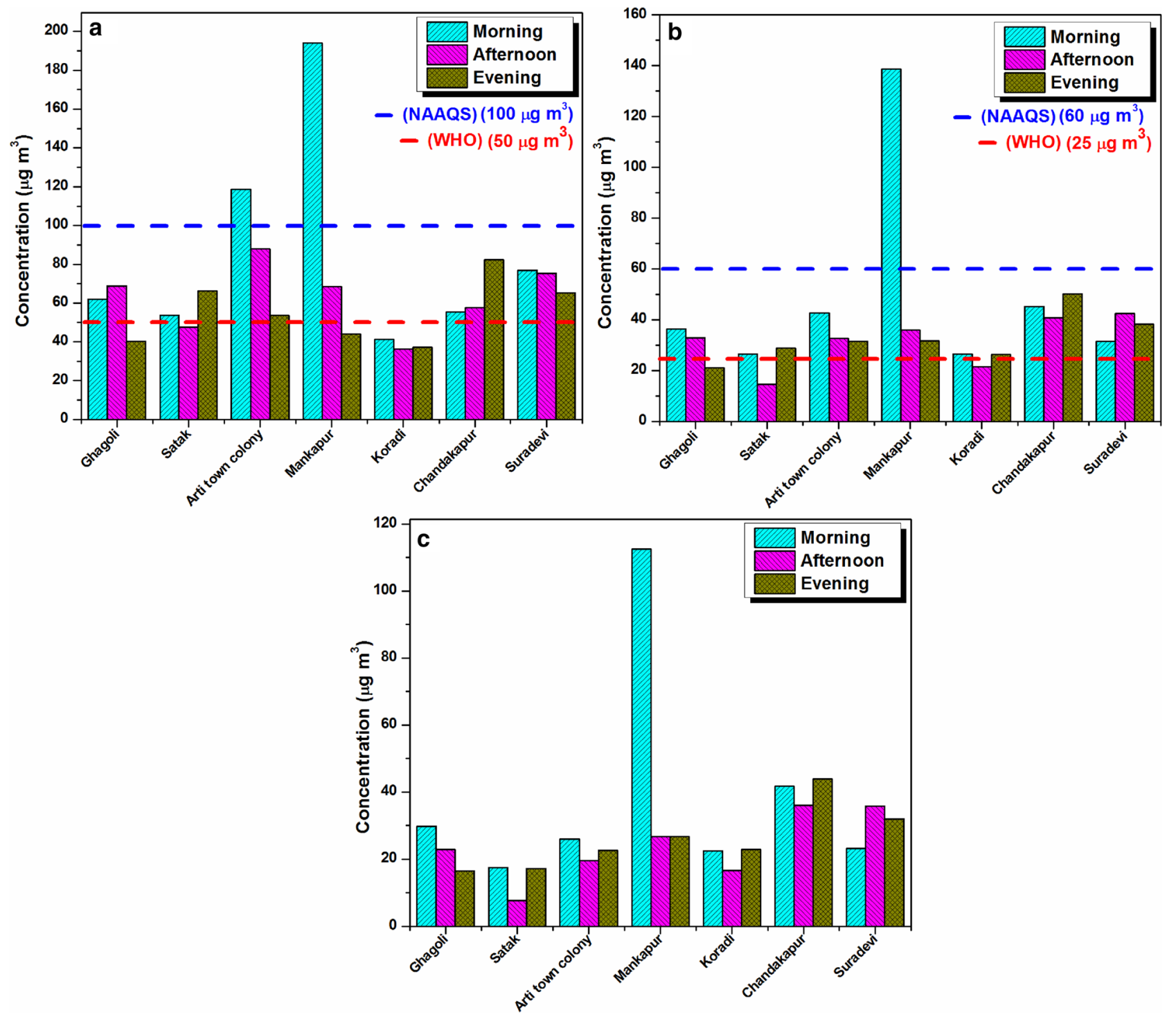

Fig. 4 Convention of particulate matter in three timings morning, afternoon and evening a $\mathrm{PM}_{10}, \mathbf{b} \mathrm{PM}_{2.5}$ and $\mathbf{c} \mathrm{PM}_{1}$ 
Table 3 Average concentration of $\mathrm{PM}_{10}, \mathrm{PM}_{2.5}$, and $\mathrm{PM}_{1}$ are in $\left(\mu \mathrm{g} / \mathrm{m}^{3}\right)$ in the study area

\begin{tabular}{llllllllll}
\hline S.no & Sampling time & Air pollution & Ghagoli & Satak & Arti town colony & Mankapur & Koradi & Chandakapur & Suradevi \\
\hline 1 & Morning & $\mathrm{PM}_{10}$ & 61.95 & 53.62 & 118.62 & 193.95 & 41.22 & 55.40 & 76.87 \\
2 & & $\mathrm{PM}_{2.5}$ & 36.32 & 26.53 & 42.63 & 138.67 & 26.58 & 45.26 & 31.45 \\
3 & & $\mathrm{PM}_{1}$ & 29.69 & 17.54 & 25.96 & 112.46 & 22.51 & 41.66 & 23.13 \\
4 & \multirow{2}{*}{ Afternoon } & $\mathrm{PM}_{10}$ & 68.91 & 47.56 & 87.89 & 68.53 & 36.26 & 57.61 & 75.39 \\
5 & & $\mathrm{PM}_{2.5}$ & 32.9 & 14.61 & 32.71 & 35.98 & 21.6 & 40.73 & 42.49 \\
6 & & $\mathrm{PM}_{1}$ & 22.83 & 7.70 & 19.47 & 26.68 & 16.66 & 36.04 & 35.76 \\
7 & \multirow{2}{*}{ Evening } & $\mathrm{PM}_{10}$ & 40.42 & 66.15 & 53.61 & 43.97 & 37.21 & 82.25 & 65.33 \\
8 & & $\mathrm{PM}_{2.5}$ & 21.12 & 28.72 & 31.65 & 31.82 & 26.26 & 50.26 & 38.14 \\
9 & & $\mathrm{PM}_{1}$ & 16.52 & 17.21 & 22.63 & 26.64 & 22.84 & 43.82 & 31.98 \\
\hline
\end{tabular}

* Units: all are in $\mu \mathrm{g} / \mathrm{m}^{3}$

NAAQS PM $10: 100 \mu \mathrm{g} / \mathrm{m}^{3} \mathrm{PM}_{2.5}: 60 \mu \mathrm{g} / \mathrm{m}^{3}$

WHO PM $10: 50 \mu \mathrm{g} / \mathrm{m}^{3} \mathrm{PM}_{2.5}: 25 \mu \mathrm{g} / \mathrm{m}^{3}$

\subsection{Secondary health data analysis}

\subsubsection{Periodic prevalence of the asthma}

A bar chart representation of the total number of male and female asthma patients attending the health center is shown in Fig. 5a-c. Figure 5 a shows the periodic prevalence of asthma in percentage, it provides the periodic prevalence of the disease, which can be comparable across health centers. In Chicholi, during 2012, the periodic prevalence of the disease was $0.03 \%$, which was marginally lower in the next year, i.e., 2013, that was $0.02 \%$. The highest periodic prevalence was observed for Dhapewada PHC for the two years, which were $0.05 \%$ and $0.06 \%$ for the years 2012 and 2013, respectively. During the summer season, it was observed that the dispersion of air pollutants is higher in summer that could be a contributing factor for the higher prevalence of respiratory diseases observed in summer $[29,30]$. Figure $5 b$ shows the distribution of asthma patients attending health centers during the post-monsoon season. The periodic prevalence for each health center for the years 2012 and 2013 was obtained, as shown in Fig. 5b. The prevalence was higher at Dorli center with values $0.07 \%$ and $0.09 \%$ for the years 2012 and 2013, respectively. The lowest prevalence was obtained for Kanhan PHC with values of $0.01 \%$ and $0.04 \%$ for the years 2012 and 2013. Overall, the periodic prevalence at all the PHCs was higher in the post-monsoon season as compared to the summer season. Figure $5 \mathrm{c}$ shows the distribution of asthma patients attending health centers during the winter season. The periodic prevalence of the disease was highest at Dhapewada $\mathrm{PHC}$ with values of $0.06 \%$ and $0.05 \%$ for the years 2012 and 2013, respectively. This was followed by the prevalence rates at Chicholi PHC with values of $0.04 \%$ and $0.03 \%$ in 2012 and 2013. Other centers hardly reported any cases of asthma attacks during this season, resulting in low periodic prevalence rates. Similarly, the authors [31] estimated the number of thermal power plants in India and reported its impacts on human health. The amount of coal consumption in 2014 was 660 million tons for the generation of $159.1 \mathrm{GW}$ of power and it is predicted to increase $457.9 \mathrm{GW}$ in 2030 with the utilization of coal 1799 million tons. Adappa et al. [32] have correlated the amount of $\mathrm{PM}_{2.5}$ generated from the power plants and their impact on the premature mortality and asthma attacks. The asthma attacks are increased in the manner 23.4 million in the year 2017, 28.4 million in 2020, 36.7 million in 2025 and 42.7 million in the year 2030, respectively. They also studied the effect of coalbased thermal power plant emission and its impact on surrounding population's health status and environmental condition within $5 \mathrm{~km}$ radios keeping thermal power plant as a center. It was clearly observed that there was health impact on the surrounding population similar to the present study. The literature mentioned that majorly the age group above 45 years are getting adversely effected and among the population affected are about $82.8 \%$ were female and $12.2 \%$ were male. The participant's in their study showed about $4.2 \%$ had wheeze, $26.7 \%$ had cough, $16.7 \%$ had phlegm, $1.5 \%$ had chest pain, $6.6 \%$ had shortness of breath and $9.8 \%$ had allergic symptoms such as sneezing, eye irritation and skin itching. The results from both the literature and the present study confirm that the prevalence of health effects majorly is due to inhalation of emissions from the thermal power plant.

\subsubsection{Average annual prevalence (AAP) of asthma}

The average annual prevalence (AAP) of the disease across health centers is shown in Table.4. It shows that the average annual prevalence of asthma over two years based on the number of patients was below $1 \%$ in all 
Fig. 5 a Periodic prevalence of asthma in percentage during summer season, $\mathbf{b}$ periodic prevalence of asthma in percentage during post-monsoon season and c periodic prevalence of asthma in percentage during winter season
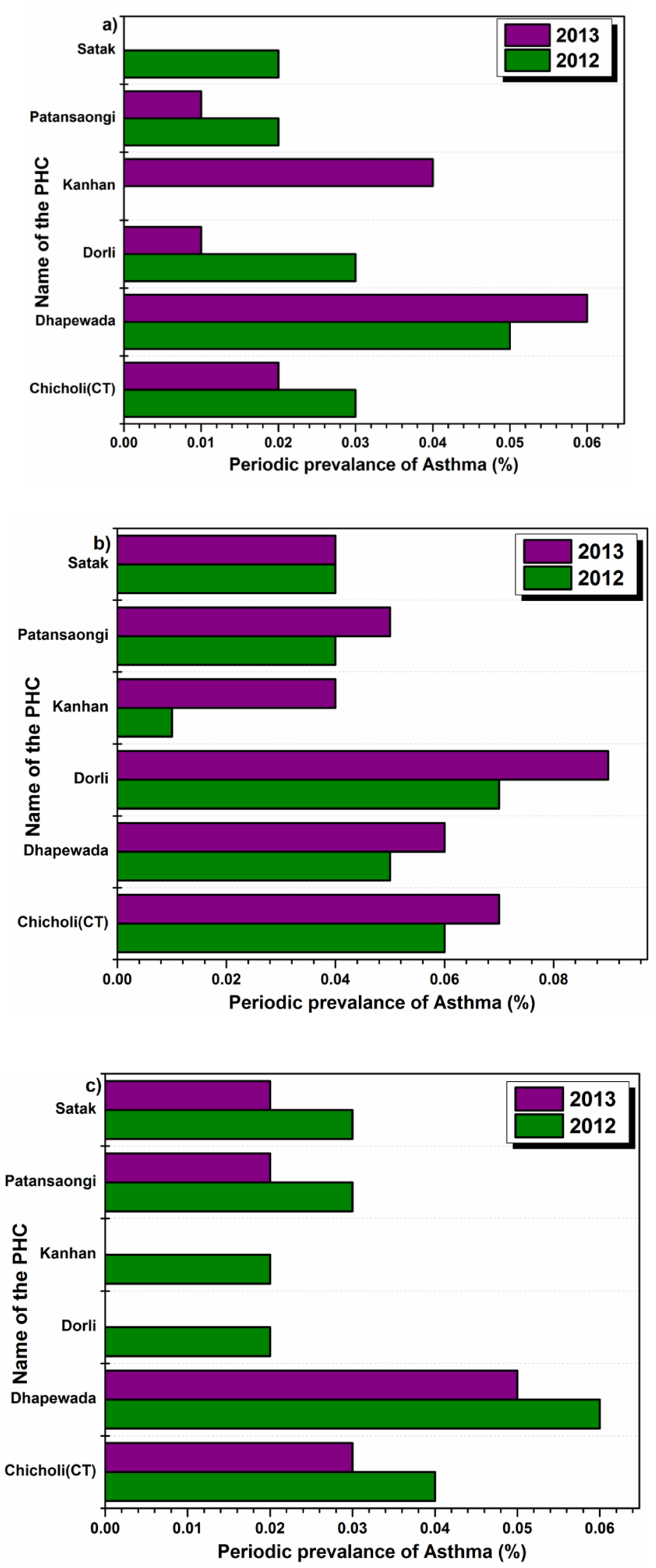

SN Applied Sciences 
Table 4 Average annual prevalence (AAP) of the disease across health centers

\begin{tabular}{lll}
\hline Primary health center & Diseases & AAP (\%) \\
\hline Dhapewada & Asthma & 0.581 \\
Patansaongi & Asthma & 0.218 \\
Chicholi (CT) & Asthma & 0.201 \\
Satak & Asthma & 0.155 \\
Droli & Asthma & 0.377 \\
Kanhan & Asthma & 0.198 \\
\hline
\end{tabular}

the centers. It was highest at Dhapewada center (0.581), followed by Dorli (0.377), Patansawangi (0.218), Chicholi $(0.201)$ and Kanhan (0.198). The lowest was reported in the Satak center (0.155).

\subsubsection{Periodic prevalence of UTRI}

A bar chart representation of the number of cases of upper respiratory tract infections is shown in Fig. 6a-c. The figure shows the number of occurrences of UTRI cases across different PHCs in an absolute sense. The cases were maximum in Patansawangi center compared to others.

Figure 6a shows the distribution of upper respiratory tract infections cases according to $\mathrm{PHC}$, along with the periodic prevalence of the disease in the summer season. It provides the distribution of patients attending health centers and is diagnosed with upper respiratory tract infections during the summer season. It is evident from the figure that the periodic prevalence of the disease was higher for Dorli and Patansaongi PHCs as compared to others. The prevalence was at least for the Chicholi center. Figure $6 \mathrm{~b}$ shows the distribution of upper respiratory tract infections cases according to $\mathrm{PHC}$, along with the periodic prevalence of the disease in the postmonsoon season. It provides the statistics for UTI for the post-monsoon season. It is evident from the figure that the periodic prevalence of Dorli and Patansawangi was much higher than in other health centers. Again, the least prevalence was observed as Chicholi health center in the post-monsoon season. Figure $6 \mathrm{c}$ shows the distribution of upper respiratory tract infections cases according to $\mathrm{PHC}$, along with the periodic prevalence of the disease in the winter season. It gives the patient data on the number of UTI cases attending health centers during the winter season. Again in this season, the periodic prevalence at Dorli was maximum, followed by the majority at Patansawangi. Chicholi, as well as Dhapewada centers, showed the least prevalence as compared to other centers Table 5.
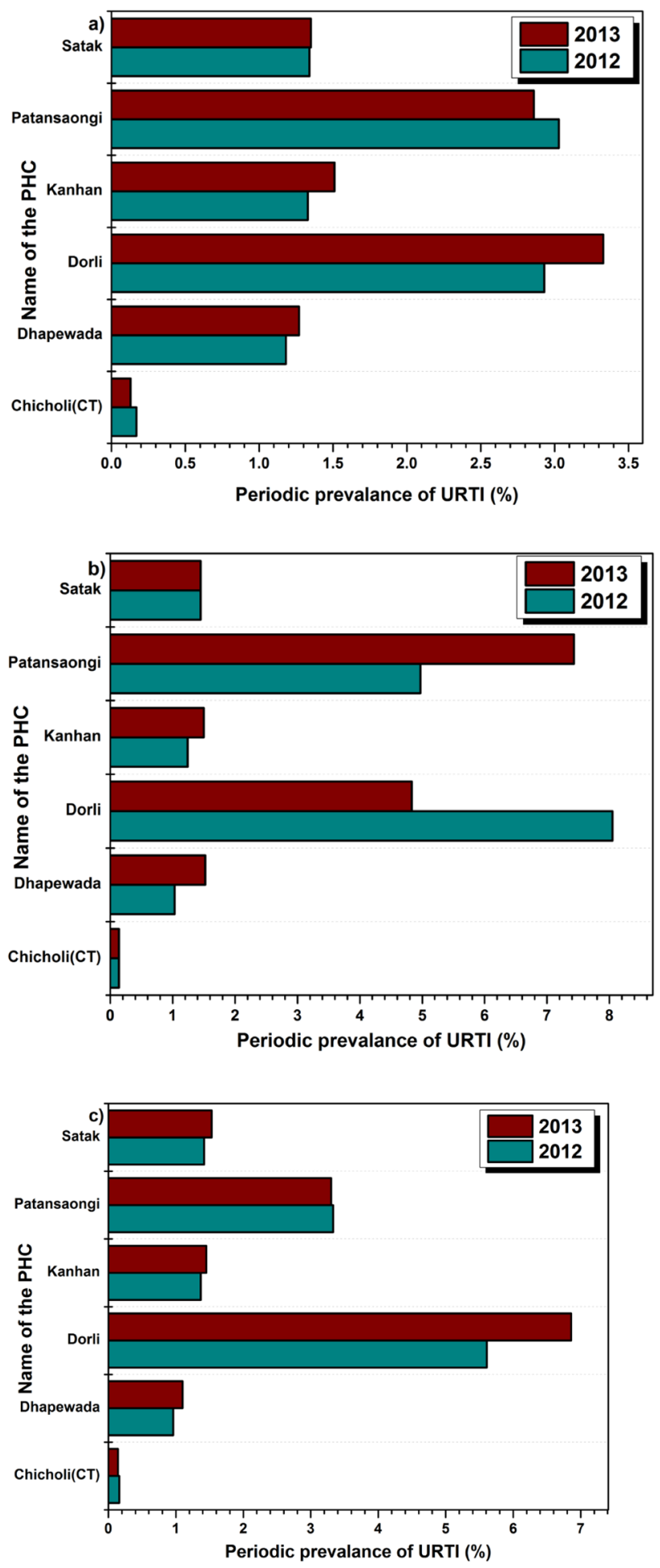

Fig. 6 a Periodic prevalence of the upper respiratory tract infection (URTI) disease during summer season, $\mathbf{b}$ periodic prevalence of the upper respiratory tract infection (URTI) disease during post-monsoon season and c periodic prevalence of the upper respiratory tract infection (URTI) disease during winter season 
Table 5 Average annual prevalence (AAP) of the disease across health centers

\begin{tabular}{llr}
\hline Primary health center & Diseases & AAP (\%) \\
\hline Dhapewada & Upper respiratory tract infections & 24.961 \\
Patansaongi & Upper respiratory tract infections & 40.693 \\
Chicholi (CT) & Upper respiratory tract infections & 0.769 \\
Satak & Upper respiratory tract infections & 12.775 \\
Droli & Upper respiratory tract infections & 28.605 \\
Kanhan & Upper respiratory tract infections & 14.898 \\
\hline
\end{tabular}

\subsubsection{The annual average prevalence of URTI}

The average annual prevalence (AAP) of the disease across health centers is presented in reported in each health center. It shows that the highest average prevalence of UTI based on 2012 and 2013 data was at Patansawangi health center $(40.693 \%)$, followed by Dorli (28.605\%), Dhapewada (24.961\%) and then Kanhan (14.898\%). The least was obtained for Chicholi, i.e., $0.769 \%$. Likewise, the annual average prevalence of any disease can be determined so as to decide its severity in and among the population.

The results observed the average annual prevalence (AAP) of asthma and URTI of hospitalization of the population residing near the thermal power plant. The air particulate matter (PM) has been associated with direct and indirect adverse health impacts, including asthma attacks, respiratory diseases and URTI [33-35]. Lagorio et al. [36] reported respiratory problems in the participants residing nearby thermal power plants due to particulate matter exposure. Landrigan et al. [37] reported that exposure to air pollutants emitted from the CFTPP can cause respiratory diseases. Lam et al. [38] reported increased incidences of COPD in the subject exposed to coal-fired TPP emissions. Recent studies carried out by other authors in the study area confirm increase incidences of respiratory disorders in the population residing in this area. Wadpalliwar [39] studied the effect of Khaperkheda thermal power plant on people residing in surround area. Authors reported that in Khaparkheda area 6531 people fell prey to respiratory ailments like asthma, upper respiratory tract infection (URI) and skin ailments, whereas the occurrence of these diseases was very low (1459) in Katol area which is at the distant place to the thermal power plant. Occurrence of UTRI in Khaperkheda area was 5893 compared to 856 in Katol area. Similarly, Dahiya [40] studied the effect of construction of new units to the Koradi Thermal Power Station. The extension of two new units leads to increase in the emissions from the plant to the surrounding area. The study reveals 150 numbers of premature deaths annually and also deaths of ten children under the age of five years.

\section{Conclusion}

The present study demonstrated increased average annual prevalence of upper respiratory tract infection (UTRI) in the central Indian population residing near the coal-fired thermal power plants. The results obtained via dispersion modeling and real-time air quality monitoring revealed that the concentration of particulate matter in the study area is gradually increasing. This is a matter of great concern as this may cause adverse health impacts on the population residing in the study area. The average annual prevalence (AAP) of UTRI was observed higher in the majorty locations. The results for the dispersion modeling distribution of air pollutant $\mathrm{PM}_{10}$ showed that the spatial distribution was associated with seasonal meteorological conditions, the maximum concentration of $\mathrm{PM}_{10}$ was observed in the summer season followed by post-monsoon and winter [41]. It could be attributed to the higher concentrations of particulate matter in the study area. Future studies may be focused on the personalized bio-monitoring of selected test subjects in the study area and source apportionment studies using receptor modeling to ascertain the association between the exposure to particulate matter and the prevalence of UTRI.

Acknowledgements Authors are thankful to the Director, CSIR-NEERI, Nagpur, India, for encouraging and kind permission for publishing the article. The first author of this publication is supported by the Department of Science \& Technology (DST), India (DST INSPIRE fellowship IF150187) for providing funding.

\section{Compliance with ethical standards}

Conflict of interest The authors declare that they no competing interest.

Open Access This article is licensed under a Creative Commons Attribution 4.0 International License, which permits use, sharing, adaptation, distribution and reproduction in any medium or format, as long as you give appropriate credit to the original author(s) and the source, provide a link to the Creative Commons licence, and indicate if changes were made. The images or other third party material in this article are included in the article's Creative Commons licence, unless indicated otherwise in a credit line to the material. If material is not included in the article's Creative Commons licence and your intended use is not permitted by statutory regulation or exceeds the permitted use, you will need to obtain permission directly from the copyright holder. To view a copy of this licence, visit http://creativecommons .org/licenses/by/4.0/.

\section{References}

1. Dudley B (2017) Summary for policymakers. In: Intergovernmental Panel on Climate Change (ed) Climate change 2013 - The 
physical science basis. Cambridge University Press, Cambridge, pp 1-30. https://doi.org/10.1017/CBO9781107415324.004

2. Sharma R, Pervez S (2004) A case study of spatial variation and enrichment of selected elements in ambient particulate matter around a large coal-fired power station in central India. Environ Geochem Health 26:373-381

3. Sharma R, Pervez Y, Pervez S (2005) Seasonal evaluation and spatial variability of suspended particulate matter in the vicinity of a large coal-fired power station in India: a case study. Environ Monit Assess. https://doi.org/10.1007/s10661-005-1008-y

4. Guttikunda SK, Jawahar P (2014) Atmospheric emissions and pollution from the coal-fired thermal power plants in India. Atmos Environ 92:449-460. https://doi.org/10.1016/j.atmos env.2014.04.057

5. Suman GS, Pal AK (2010) Source apportionment of respirable particulate matter using principal component analysis - a case study from India. Int J Appl Environ Sci 5(6):909-921

6. Shanthakumar S, Singh DN, Phadke RC (2008) Flue gas conditioning for reducing suspended particulate matter from thermal power stations. Prog Energy Combust Sci 34:685-695. https:// doi.org/10.1016/j.pecs.2008.04.001

7. Koplitz SN, Jacob DJ, Sulprizio MP, Myllyvirta L, Reid C (2017) Burden of disease from rising coal-fired power plant emissions in Southeast Asia. Environ Sci Technol 51:1467-1476. https:// doi.org/10.1021/acs.est.6b03731

8. Küçükaçıl Artun G, Polat N, Yay OD, Özden Üzmez Ö, Arı A, Tuna Tuygun G, Elbir T, Altuğ H, Dumanoğlu Y, Döğeroğlu T, Dawood A, Odabasi M, Gaga EO (2017) An integrative approach for determination of air pollution and its health effects in a coal fired power plant area by passive sampling. Atmos Environ 150:331345. https://doi.org/10.1016/j.atmosenv.2016.11.025

9. Pu Y, Song J, Dong L, Yang W, Wang S, Wang X (2019) Estimating mitigation potential and cost for air pollutants of China's thermal power generation: a GAINS-China model-based spatial analysis. J Clean Prod 211:749-764. https://doi.org/10.1016/j. jclepro.2018.11.213

10. Zhang $Y$ (2019) Coal-fired power plants and pollutant emissions, in Adv. Ultra-Low Emiss. Control technol. Coal-fired power plants. Elsevier, Hoboken, pp 1-23

11. G.J. Engineering, (2011) Global journal engineering and applied sciences - ISSN 2249-2631(online): 2249-2623(Print), 1 82-86.

12. Zhao Y, Wang S, Nielsen CP, Li X, Hao J (2010) Establishment of a database of emission factors for atmospheric pollutants from Chinese coal-fired power plants. Atmos Environ 44:1515-1523. https://doi.org/10.1016/j.atmosenv.2010.01.017

13. Jayasekher T (2009) Aerosols near by a coal fired thermal power plant: Chemical composition and toxic evaluation. Chemosphere 75:1525-1530. https://doi.org/10.1016/j.chemospher e.2009.02.001

14. Penney S, Bell J, Balbus J (2009) Estimating the health impacts of coal-fired power plants receiving international financing. Environmental defense fund, $\mathrm{p} 9$

15. Atkinson RW, Ross Anderson $\mathrm{H}$, Sunyer J, Ayres JON, Baccini M, Vonk JM, Boumghar A, Forastiere F, Forsberg B, Touloumi G (2001) Acute effects of particulate air pollution on respiratory admissions: results from APHEA 2 project. Am J Respir Crit Care Med 164:1860-1866

16. Sinharay R, Gong J, Barratt B, Ohman-Strickland P, Ernst S, Kelly FJ, Zhang J, Collins P, Cullinan P, Chung KF (2018) Respiratory and cardiovascular responses to walking down a traffic-polluted road compared with walking in a traffic-free area in participants aged 60 years and older with chronic lung or heart disease and age-matched healthy controls: a randomised, crosso. Lancet. 391:339-349. https://doi.org/10.1016/S0140-6736(17)32643-0

17. Perera F, Li TY, Zhou ZJ, Yuan T, Chen YH, Qu L, Rauh VA, Zhang $Y$, Tang D (2008) Benefits of reducing prenatal exposure to coal-burning pollutants to children's neurodevelopment in China. Environ Health Perspect 116:1396-1400. https://doi. org/10.1289/ehp.11480

18. Samoli E, Nastos PT, Paliatsos AG, Katsouyanni K, Priftis KN (2011) Acute effects of air pollution on pediatric asthma exacerbation: evidence of association and effect modification. Environ Res 111:418-424

19. Moghtaderi M, Zarei M, Farjadian S, Shamsizadeh S (2016) Prediction of the impact of air pollution on rates of hospitalization for asthma in Shiraz based on air pollution indices in 2007-2012. Open J Air Pollut 05:37-43. https://doi.org/10.4236/ ojap.2016.52004

20. J.A. Ortega-García, I. Martínez-Hernández, E. Boldo, A. CárcelesÁlvarez, C. Solano-Navarro, R. Ramis, E. Aguilar-Ros, M. SánchezSolis, F. López-Hernández, (2020) Urban air pollution and hospital admissions for asthma and acute respiratory disease in Murcia city (Spain), An. Pediatría (English Ed. 93 95-102. https:// doi.org/https://doi.org/10.1016/j.anpede.2020.01.006.

21. Shakerkhatibi $M$, Dianat I, Asghari Jafarabadi $M$, Azak R, Kousha A (2015) Air pollution and hospital admissions for cardiorespiratory diseases in Iran: artificial neural network versus conditional logistic regression. Int J Environ Sci Technol 12:3433-3442. https ://doi.org/10.1007/s13762-015-0884-0

22. Ostro B, Roth L, Malig B, Marty M (2009) The effects of fine particle components on respiratory hospital admissions in children. Environ Health Perspect 117:475-480

23. Zhang $X Y$, Gong $S L$, Zhao TL, Arimoto R, Wang $Y Q$, Zhou ZJ (2003) Sources of Asian dust and role of climate change versus desertification in Asian dust emission. Geophys Res Lett. https ://doi.org/10.1029/2003GL018206

24. Holmes NS, Morawska L (2006) A review of dispersion modelling and its application to the dispersion of particles: an overview of different dispersion models available. Atmos Environ 40:5902-5928. https://doi.org/10.1016/j.atmosenv.2006.06.003

25. Abdul-Wahab S, Sappurd A, Al-Damkhi A (2011) Application of California Puff (CALPUFF) model: a case study for Oman, clean Technol. Environ Policy 13:177-189. https://doi.org/10.1007/ s10098-010-0283-7

26. Choi Y-J, Fernando HJS (2007) Simulation of smoke plumes from agricultural burns: application to the San Luis/Rio Colorado airshed along the U.S./Mexico border. Sci Total Environ 388:270289. https://doi.org/10.1016/j.scitotenv.2007.07.058

27. Bunnell JE, Garcia LV, Furst JM, Lerch H, Olea RA, Suitt SE, Kolker A (2010) Coal combustion and respiratory health near Shiprock, New Mexico. J Environ Public Health 2010:1-14. https://doi. org/10.1155/2010/260525

28. World Health Organization (2010) WHO guidelines for indoor air quality: selected pollutants. The WHO European Centre for Environment and Health, Bonn Office, WHO Regional Office for Europe coordinated the development of these WHO guidelines, Denmark, pp 1-484. ISBN 9789289002134

29. Carugno M, Consonni D, Randi G, Catelan D, Grisotto L, Bertazzi PA, Biggeri A, Baccini M (2016) Air pollution exposure, causespecific deaths and hospitalizations in a highly polluted Italian region. Environ Res 147:415-424. https://doi.org/10.1016/j. envres.2016.03.003

30. Baccini M, Biggeri A, Grillo P, Consonni D, Bertazzi PA (2011) Health impact assessment of fine particle pollution at the regional level. Am J Epidemiol 174:1396-1405. https://doi. org/10.1093/aje/kwr256

31. Guttikunda SK, Jawahar P (2018) Evaluation of particulate pollution and health impacts from planned expansion of coalfired thermal power plants in India using WRF-CAMx modeling system. Aerosol Air Qual Res 18:3187-3202. https://doi. org/10.4209/aaqr.2018.04.0134 
32. Adappa S, Tiwari R, Kamath R, Guddattu V (2017) Health effects and environmental issues in residents around coal fired thermal power plant Padubidri: a cross sectional study. J Environ Occup Sci. https://doi.org/10.5455/jeos.20170215104352

33. Jena S, Singh G (2017) Human health risk assessment of airborne trace elements in Dhanbad, India. Atmos Pollut Res 8:490-502. https://doi.org/10.1016/j.apr.2016.12.003

34. Zallaghi E, Geravandi S, Nourzadeh Haddad M, Goudarzi G, Valipour L, Salmanzadeh S, Hashemzadeh B, Zahedi A, Mohammadi MJ, Soltani F (2015) Estimation of health effects attributed to nitrogen dioxide exposure using the AirQ model in Tabriz City Iran Heal. Scope. https://doi.org/10.17795/jhealthscope-30164

35. Minichilli F, Gorini F, Bustaffa E, Cori L, Bianchi F (2019) Mortality and hospitalization associated to emissions of a coal power plant: a population-based cohort study. Sci Total Environ 694:133757. https://doi.org/10.1016/j.scitotenv.2019.133757

36. Lagorio S, Forastiere F, Pistelli R, lavarone I, Michelozzi P, Fano V, Marconi A, Ziemacki G, Ostro BD (2006) Air pollution and lung function among susceptible adult subjects: a panel study. Environ Heal 5:11. https://doi.org/10.1186/1476-069X-5-11

37. Landrigan PJ, Fuller R, Acosta NJR, Adeyi O, Arnold R, Basu N, Baldé AB, Bertollini R, Bose-O'Reilly S, Boufford Jl, Breysse PN, Chiles T, Mahidol C, Coll-Seck AM, Cropper ML, Fobil J, Fuster V, Greenstone $M$, Haines A, Hanrahan D, Hunter D, Khare M, Krupnick A, Lanphear B, Lohani B, Martin K, Mathiasen KV, McTeer MA, Murray CJL, Ndahimananjara JD, Perera F, Potočnik J, Preker
AS, Ramesh J, Rockström J, Salinas C, Samson LD, Sandilya K, Sly PD, Smith KR, Steiner A, Stewart RB, Suk WA, van Schayck OCP, Yadama GN, Yumkella K, Zhong M (2017) The lancet commission on pollution and health. Lancet. https://doi.org/10.1016/S0140 $-6736(17) 32345-0$

38. Lam KBH, Yin $P$, Jiang $C Q$, Sen Zhang W, Adab P, Miller MR, Thomas GN, Ayres JG, Lam TH, Cheng KK (2012) Cheng, past dust and GAS/FUME exposure and COPD in Chinese: the Guangzhou Biobank Cohort study. Respir Med 106:1421-1428. https://doi. org/10.1016/j.rmed.2012.05.009

39. Roy A (2016) Power plants making Khaparkheda residents ill. Times of India, 1-2, Mar 3, 2016

40. Behl M (2019) Analysis reveals 10 kids under 5 may die annually after 2 units are added to Koradi power plant. Times of India, Jul 15,2019

41. Lee HD, Yoo JW, Kang MK, Kang JS, Jung JH, Oh KJ (2014) Evaluation of concentrations and source contribution of PM10 and SO2 emitted from industrial complexes in Ulsan, Korea: interfacing of the WRF-CALPUFF modeling tools. Atmos Pollut Res 5:664-676. https://doi.org/10.5094/APR.2014.076

Publisher's Note Springer Nature remains neutral with regard to jurisdictional claims in published maps and institutional affiliations. 